\title{
Awareness and Health Risk Protection Behaviours of Scavengers in the Gbalahi Landfill Site in the Era of Sustainable Development, Ghana
}

Joseph Gyea Nuripuoh

University for Development Studies

Abudu Ballu Duwiejuah ( $\sim$ abalu096@gmail.com )

University for Development Studies

Noel Bakobie

University for Development Studies

\section{Research Article}

Keywords: Health risks, landfill, perceptions, solid waste, waste scavengers

Posted Date: October 1st, 2021

DOI: https://doi.org/10.21203/rs.3.rs-948709/v1

License: @ (i) This work is licensed under a Creative Commons Attribution 4.0 International License. Read Full License

Version of Record: A version of this preprint was published at Discover Sustainability on January 4th, 2022. See the published version at https://doi.org/10.1007/s43621-021-00070-7. 


\section{Abstract}

Scavenging is a pivotal in achieving sustainable waste management, environment health and economic development. The purpose of the study was to assess the practices, knowledge, perception and health risk protection behaviours of waste scavengers in the Gbalahi landfill site. A total of 60 scavengers were conveniently sampled and interviewed. The study showed $83 \%$ of the respondents had an average monthly income between GHc 1.00 to GHç 100.00 whereas $17 \%$ had between GHc 101.00 to $\mathrm{GH}$ C 300.00. The study also revealed 93\% of the respondents sort waste using hooks and their bare hands. The respondents that have ever been physically abused by other scavengers were $62 \%$. A significant number of scavengers believed they have been fortified against "dirt diseases" during their childhood and have developed natural immunity against diseases. The knowledge of scavengers was skewed towards economic benefits as

they viewed scavenging as a survival strategy. Safety and protection practices are limited to the use of pieces of clothes to cover the nose, wearing of multiple clothes and worn-out boots recovered from the landfill. Discrimination and physical abuse posed a seemingly significant psychological health risk to majority of them. Covid-19 health risks behaviours, majority of the respondents risk being exposed to the virus and pathogens. Scavengers should be provided with personal protective equipment and / or strictly made to obey safety and protection protocols.

\section{Introduction}

Solid waste management is a major problem for most communities around the world and in recent years, world cities generate approximately 1.3 billion tonnes of solid waste every year, which is projected to increase to 2.2 billion tonnes by 2025 [1]. This observed phenomenon has significantly increased the cost of waste management globally. Globally, $70 \%$ of the total waste generated which is solid waste ends up at the landfill [1]. Most landfill sites in Ghana are essentially open dumps without leachate or gas recovery systems hence operate below the acceptable environmental health standards [2]. Scavenging therefore have the potential of reducing the quantum of waste in the environment, extending the lifespan of landfills, creating employment as well as generating economic returns [3].

Scavenging is a very important and common waste management activity in most developing countries and has a myriad of economic and environmental benefits. Scavenging provides employment for about $2 \%$ of the population in third world cities [4]. Cities such as Karachi, Manila, Jakarta and Bangkok save about \$3 million dollars annually owing to the activities of scavengers [4]. The World Bank estimates that scavenging (waste recovery) provides a means of survival for about $1 \%$ of the population in African, Asian, and Latin American cities [5]. Recovered waste may be sold by scavengers for the purpose of recycling or reuse. This comes at the risk of adverse occupational and health hazards [3], however the activities of scavengers may seem to be sustainable waste management and development strategy.

Scavengers faced diverse problems and health hazards during scavenging. Six-point classification of hazards and risks to which scavengers can be exposed which include: occupational accidents (injuries such as cuts), physical risk caused by working under all sorts of weather, chemical risks (inhaling toxic gasses), psychological risks (sexual harassment, low self-esteem and hallucinations), biological risks (intestinal protozoa, helminthes, eye infections, skin diseases, diarrhoea and human immunodeficiency virus (HIV) / acquired immunodeficiency syndrome (AIDS)) and general hazards resulting from bites and stings from insects, scorpions, dogs, snakes amongst others [6].

Scavengers operate under perilous conditions without personal protective equipment (PPE) and are often prone to microbial infections, bites, cuts amongst others [5, 7]. Scavengers can be pathways for the transmission of communicable diseases owing to their association with solid waste and the wider public and as such their health must be of public concern [8]. This study therefore sought to assess the practices, knowledge, perception and health risk protection behaviours of solid waste scavengers in the Gbalahi landfill site. 


\section{Literature Review}

\section{Scavenging}

A waste scavenger can generally be described as any person who is involved in the recovery or salvaging of materials with the potential for reuse and recycle in order to sell or for personal consumption [9]. Scavenging as an informal sector initiative in solid waste management, generally stems from the premise that some economically useful materials can be recovered from solid waste that has been discarded or disposed [10]. Scavenging has both economic and environmental benefits, it serves as a source of employment and income to unemployed individuals, supplying inexpensive raw materials to industries, it also reduces the demand for collection, transport and disposal equipment and facilities. The recycling of materials as a result of scavenging has a lower environmental impact as compared with the use of virgin resources. Scavenging is a common occurrence in third World countries owing to the prevalence of high unemployment, widespread poverty and the lack of a safety net for the poor $[9,11]$.

\section{Four motivational theories or schools of thought for scavenging}

Navarrete-Hernandez [12] identifies four motivational theories or schools of thought for scavenging thus the dualist, structuralist, neoliberal and co-production theories. Dualist's theorists argue that scavenging from the waste stream stems from stagnating economic growth and unavailability of formal employment. Dualist theorists further believe that, there is an inverse relationship between the number of people employed as waste pickers (scavengers) and economic growth. Dualist policies in relation to waste pickers are generally repressive and based on the premise that increased employment generation in the formal jobs would reduce the population of people employed as scavengers or waste pickers [12].

Structuralist's perceive scavenging as major element of the capitalist system. Scavenging serves as a means of meeting the demand for recyclable materials from formal enterprises. Industries and other formal enterprises are able to reduce cost of production and increase returns owing to the availability of low-cost recyclable materials as a result of waste picking $[12,13]$. Waste picking generally reduces the cost of production. Structuralist theorists are of the conception that, there exist a positive relationship between waste picking and economic growth. Structuralist policies promote waste-picker associations and unions, in order to reinforce waste pickers' power to negotiate better prices and working conditions $[12,13]$.

Neoliberals perceive scavengers / waste pickers as small-scale entrepreneurs [14]. Based on this premise, scavenging / waste picking can be said to be intricately linked to the formal industry in the following ways. Firstly, scavenging at the industrial level provides local industries with affordable or cheap substitutes for raw materials thus reducing the cost of production and subsequently maximising profits and competitiveness at the industrial level. Secondly, the formal market of raw materials determines the types of substitute materials that are in demand and the prices paid to waste pickers and as such scavenging is inextricably linked to the level of competitiveness of local industries. Neoliberals posits that there is an inverse / negative relationship between waste picking and economic growth [14]. In times of economic crisis, the depreciation of local currencies results in an upsurge in the prices of imported raw materials and this in turn results in an increase in the demand for cheaper substitutes or raw materials recovered by scavengers / waste pickers. Neoliberals believe that scavenging is a highly efficient activity plagued by regulatory bottlenecks and a lack of legislation or policy direction resulting in the inability of waste pickers to achieve their utmost economic potential [12].

With co-production theory, a burgeoning number of researchers / academics are canvassing for the recognition and prioritisation of the role of the informal economy as an important player in the provision of public services in developing countries [12]. [15] argued that the monopoly enjoyed by the state in the provision of essential public services and the 
newfangled public management strategy of privatization have fallen short in providing standard public services in most developing countries as a result of logistical constraints and governance inefficiencies. Logistical constraints and failures maybe related to the provision of public services to deprived communities who are widely dispersed in terms of geography and do not have the capacity to pay for the services rendered. Governance inefficiency and failure on the other hand results from an institutional lack of capacity to ensure a sustained provision of public services whilst achieving a sustainable financing system [15].

The setbacks stems from the conventional "supply-led engineers" approach which is premised on capital intensive investments, high cost of operation and high standards for developing countries characterised by high availability of labour, low governance capacity and limited investment capacity [16]. [17] posits that "co-production" arrangements through which a long-term partnership, citizens and the state are able to assemble resources to provide goods and services for the public, presents an intervening opportunity or solution for the delivery of basic services in developing countries. [15] proposed that co-production with the informal economy should not be overlooked since it has the prospects of being the best alternative in the provision of essential public services. Public sector support is pivotal in order to increase the productivity of waste-pickers under the co-production theory, consequently, this will optimise the economic efficiency, social equity and positive environmental impacts of waste picking or scavenging.

\section{Health risks and hazards of scavenging}

Health and safety is: "the promotion and maintenance of the highest degree of physical, mental and social well-being of workers in all occupations; the prevention amongst workers of departures from health caused by their working conditions; the protection of workers in their employment from risks resulting from factors adverse to health; the placing and maintenance of the worker in an occupational environment adapted to his physiological and psychological capabilities; and to summarise, the adaptation of work to man and of each man to his job" [9]. Health and safety generally involves the process of assessing risks and making changes to systems and mechanisms such that these risks are prevented or mitigated. Health risks maybe influenced by the following factors; the type of work, prevailing environmental conditions within which the work is situated, predisposed or pre-existing health conditions of the worker and resource availability to improve working conditions and maintain standards [9].

Health determines one's mental and physical fitness and capability of functioning effectively for the good and benefit of society [18]. Health as [18] suggests, is dependent on the environment. [18] further suggests that, health is a product welfare. Lower welfare results in bad health and bad health limits the realisation of higher welfare. Health problems associated with solid waste scavenging were greatly influenced by the environment. A study conducted by the World Bank in a Mexico City dumpsite revealed that the average lifespan of waste pickers / scavengers on the landfill was about 39 years [19]. [20] classified the health risks and hazards associated with scavenging into six broad thematic areas which includes; chemical hazards, infection, ergonomic and musculoskeletal damage, mechanical trauma, emotional wellbeing and vulnerabilities, and environmental contamination.

\section{Methodology}

\section{Study area}

Tamale landfill site is located in Gbalahi in the Sagnarigu Municipality in the Northern region of Ghana. Gbalahi shares boundaries with Kulahi to the east, Taha to the west, Wuvogumani to the north and Mali to the South (Figure 1) [21]. The landfill is located (Figure 1) within latitude 9.441 and longitude -0.759.

\section{Research setting, sample and data}


The research was descriptive this was used to broaden the scope of understanding on the perception and health risks protection behaviours of scavenging in the Gbalahi landfill site. [22] stated that qualitative methods are inductive since they seek to discover, not test, explanatory theories. Primary data was collected from January to April, 2019 using preliminary reconnaissance field surveys, focus group discussions, questionnaires, face-to-face interviews and field observations. A preliminary reconnaissance survey was conducted to be appraised with the study area and resources needed to conduct the research. This was useful in the formulation of the questionnaire and interview schedules and in understanding and appreciating the scale of waste scavenging and the scavenging practices on the landfill site. It was also used to establish contact with the leadership of the scavengers and other key informants.

Convenience sampling method was used to sample scavengers on the landfill site. This sampling technique was used because there was a general sense of apprehension by the scavengers that the research and such studies were aimed at removing them from the landfill site or waste management stream. Furthermore, solid waste scavengers at the landfill were mostly preoccupied or busy sorting and sifting through waste on the landfill. It was therefore expedient to employ convenience sampling technique.

Permission was sorted and granted by the landfill managers to carry out the research. Scavengers consent were sorted and confidentiality assured before the face-face interview and focus group discussions. The questionnaire was developed, pre-tested and used to elicit relevant information from the solid waste scavengers. A total of 60 respondents were used owing to the fact that data and theoretical saturation had been reached. The saturation criterion is widely used in qualitative research to justify and validate sample size. Data and / or theoretical saturation is attained when in the process of data collection and / or analyses it suffixes that no new elements or additional information is been added or revealed. Thus, there appears to be information redundancy and further data collection becomes counterproductive and unethical [23]. [24] agreed that data saturation is reached when "new data tend to be redundant of data already collected. In interviews, when the researcher begins to hear the same comments again and again, data saturation is being reached. It is then time to stop collecting information and to start analysing what has been collected". To confirm saturation, data collection was continued for 15 more respondents.

The face-to-face interviews were conducted using an interview guide in order to have an in-depth awareness, knowledge, perception and modus operandi as related to scavenging on the landfill site. The focus group discussion was held with a cross section of the leadership of the scavengers on the landfill as well as other quasi women and youth groups (children) each made up of a maximum of 12 participants. This method was employed in order to explicate their concerns in terms of vulnerability, discrimination, emotional and physical abuse and how they think the adverse health impacts of scavenging may be augmented. Periodic visits were made to the landfill site in order to understand and better appreciate the scope of scavenging activities on the landfill site. This was done alongside with keen observation of the use of personal protective equipment, scavenger-scavenger interactions or relationship, how waste was sorted and processed on-site amongst others.

\section{Measures Of Variables}

The questionnaire contained both open and close ended questions and categorised into four main thematic areas thus; Part A: Demographic characteristics (gender, age, marital status and education levels of scavengers), Part B: Socioeconomic status (occupation, income, working days, duration and period, marital status and education levels of scavengers), Part C: Attitudes, knowledge, practices, perception and motivation, and Part D: Health risk, protection behaviours and safety practices. 


\section{Data analysis procedure}

The statistical package for social sciences (SPSS version 25) and Microsoft office excel 2019 were used to process the quantitative data into graphs, charts, and tables for interpretation and discussion. Correlation analysis was also conducted to identify any significant statistical relationship between the study variables.

\section{Results And Discussion}

\section{Socio-demographic and economic characteristics of scavengers}

The study revealed that $63 \%$ of the respondents were males and $37 \%$ were females (Table 1 ). The study showed scavengers within the age range of less than 15 years were about 37\%, 16 - 25 years were 20\%, 26 - 35 and 36 - 45 years each representing about $22 \%$ (Table 1). Majority of the respondents were males and all the respondents were in their youthful age. This finding agrees with that of $[7,25]$ who attributed the male dominance and youthfulness to the fact that scavenging is labour intensive which requires a lot of physical strength. It may be due to the unemployment rate in Ghana and as such the youth are compelled to engage in scavenging so as to make ends meet.

The study observed $37 \%$ of the scavengers which is the highest age range were less than 15 years. This finding contrast with that of $[25,26]$ that observed that majority of scavengers were between the ages of 20 - 30 years, 31 - 40 years and 20 - 29 years, respectively. Majority of the respondents between the ages of 5 - 25 years had formal education of which $57 \%$ was primary education (Table 1). Some of the respondents with formal education were dropouts due to lack of financial support and interest in formal education. This finding is similar to that of $[7,10,25,27,28]$ that observed a high percentage in educated scavengers thus $98 \%, 87 \%, 81 \%, 87 \%$ and $71 \%$ with a significant proportion been at the primary school level. This finding however contradicts that of [29] who observed that about $60 \%$ of the scavengers in Obio/Akpor local government in Nigeria did not have any formal education. Correlation analysis showed a strong negative correlation between the age of the respondents and their level of education $\left(r=-0.661^{\star *}\right)$. The number of single, married and divorced scavengers accounted for $60 \%, 39 \%$ and $1 \%$ of the total respondents, respectively (Table 1). 
Table 1

Socio-demographic characteristics of scavengers in the Gbalahi Landfill Site

\begin{tabular}{|lll|}
\hline Gender & Frequency $(\mathbf{N}=60)$ & Percent (\%) \\
\hline Male & 38 & 63.30 \\
\hline Female & 22 & 36.70 \\
\hline Total & 60 & 100 \\
\hline Age & & \\
\hline Less than 15 years & 22 & 36.70 \\
\hline 16-25 years & 12 & 20.00 \\
\hline 26-35 years & 13 & 21.70 \\
\hline 36-45 years & 13 & 21.70 \\
\hline Total & 60 & 100 \\
\hline Level of education & & \\
\hline No formal education & 23 & 38.30 \\
\hline Primary & 21 & 35.00 \\
\hline JHS/SHS & 16 & 26.70 \\
\hline Total & 60 & 100 \\
\hline Marital status & & 38.30 \\
\hline Married & 23 & 100 \\
\hline Single & 60 & \\
\hline Divorced & & \\
\hline Total & & \\
\hline
\end{tabular}

Most of the respondents were students and few were into farming, trading, scavenging, and artisanship as their main occupation (Table 2). Almost all the respondents alluded to the fact that besides their main occupation they were also into farming. This was corroborated by the reduced scavenging activity during the rainy season since most of them had to attend to their farms.

The respondents that had an average monthly income between $\mathrm{GH} c 1.00$ to 100.00 were $83 \%$ and $17 \%$ of them earned between GHc 101.00 to 300.00 (Table 2). Only few of the respondents earned a monthly average between GHç 101.00 to 300.00 (Table 2). The average monthly income levels of scavengers may be an influential factor in the burgeoning increase in the number of scavengers. This has the potential to increase if scavenging on the landfill is made less perilous and more efficient through the provision of scavenging tools and protective equipment.

The study showed that about $99 \%$ of the respondents lived in close proximity to the landfill and were natives with $95 \%$ living in their family house and the remainder $5 \%$ living in their own house / residence. The study further revealed that, $45 \%$ of the respondents work 2 - 3 days per week, 33\% of scavengers work 4 - 6 days per week with $12 \%$ and $10 \%$ of the respondents working once a week and 7 days a week, respectively (Table 2). The respondents that work 4 - 6 hours per 
day were $62 \%$ and $38 \%$ of the respondents worked $7-12$ hours per day. The study revealed that some of the respondents within school going age were on the landfill scavenging for waste during school days. Hence, without proper regulatory measures, scavenging maybe an incentive for children of school going-age to be truant in schools and possibly drop-out of school. Reports from the Ghana Education Service (GES) and Education Management Information Systems (EMIS) data of the world bank shows that, the drop-out rate in Ghana from primary 1 to 4 remains fairly stable (1\%) but rises from $3 \%$ in primary 5 to $12 \%$ in primary 6 . In the Junior High Schools, the drop-out rate increases significantly from $3 \%$ in JHS 1 to $23 \%$ in JHS 3 [30, 31, 32].

The study also showed that about $50 \%$ of the respondents have been working as scavengers on the landfill for a period not less than four years, $37 \%$ have been working as scavengers for 1 - 3 years and the remainder $13 \%$ working for less than a year (Table 2). Half of the respondents working as scavengers on the landfill for not less than four years. This finding is similar to researches conducted by $[25,27]$. This may have dire implications since long term exposure to landfill gases and other biohazards is detrimental to their health. The respondents affirmed there is readily available market for recovered waste materials (Table 2). 
Table 2

Socio-economic characteristics of scavengers in the Gbalahi Landfill Site

\begin{tabular}{|c|c|c|}
\hline Main occupation & Frequency $(\mathrm{N}=60)$ & Percent (\%) \\
\hline Farming & 17 & 28.30 \\
\hline Trading & 10 & 16.70 \\
\hline Scavenging & 9 & 15.00 \\
\hline Student & 22 & 36.70 \\
\hline Artisanship & 2 & 3.30 \\
\hline Total & 60 & 100 \\
\hline \multicolumn{3}{|c|}{ Average monthly income of respondent (GHלे) } \\
\hline $1-100$ & 50 & 83.30 \\
\hline $101-300$ & 10 & 16.70 \\
\hline Total & 60 & 100 \\
\hline \multicolumn{3}{|l|}{ Working days / week } \\
\hline Once / week & 7 & 11.70 \\
\hline 2 - 3 days / week & 27 & 45.00 \\
\hline 4 - 6 days / week & 20 & 33.30 \\
\hline 7 days / week & 6 & 10.00 \\
\hline Total & 60 & 100 \\
\hline \multicolumn{3}{|l|}{ Working hours / day } \\
\hline 4 - 6 hrs / day & 37 & 61.70 \\
\hline 7 - 12 hrs / day & 23 & 38.30 \\
\hline Total & 60 & 100 \\
\hline \multicolumn{3}{|c|}{ How long have you been in this occupation } \\
\hline Less than 12 months & 8 & 13.30 \\
\hline $1-3$ years & 22 & 36.70 \\
\hline $4-6$ years & 10 & 16.70 \\
\hline $7-10$ years & 10 & 16.70 \\
\hline 10 years and above & 10 & 16.70 \\
\hline Total & 60 & 100 \\
\hline
\end{tabular}


Almost all the respondents scavenge waste using hooks and their bare hands (Table 3). Waste is sorted out using sticks, hooks and sometimes with the bare hands and with relatively no protective gear. The respondents also alluded that sometimes they deliberately set fire to heaps of waste on the landfill to make easy to spot metals. This practice could pose a great health and environmental risk to the scavengers and the general public [5].

Most of the respondents often recover plastics whilst few recover metals (Table 3). This finding corroborates that of [27] who found $25 \%$ of the respondents often picked plastics and $12.50 \%$ of them picked scrap metals and iron ore. Contrarily, [26] reported that metals were the most recovered material followed by plastics and bottles. Waste pickers / scavengers recycle about $50 \%$ of plastics in developing countries, which is about five times greater than the plastic recycling rate in the United States [33]. This study revealed a significant number of recovered plastics were pesticides and herbicide containers. This observation highlights a significant threat of exposure to toxic and possible carcinogenic organic compounds contained in these containers.

Majority of the respondents do not use any personal protective equipment (Table 3) with most of them less than 15 years of age. This finding learns support from $[5,25]$ that reported that scavengers do not use personal protective equipment. This study also revealed that the respondents do so because of the believed that they have been fortified (using herbs) against "dirt diseases" during their childhood and they have developed natural immunity against these diseases. [34] attributed this phenomenon to physical debilitation, lack of education to accurately assess risks, emotional disabilities and income imperatives, which prevent scavengers from protecting themselves. Children owing to their size, physiology and behaviour are more susceptible and vulnerable to environmental hazards [35]. This therefore brings into sharp focus their vulnerability to a myriad of health risks and occupational hazards because of their young age. 
Table 3

Practices, knowledge and perception of scavengers in the Gbalahi Landfill Site

\begin{tabular}{|c|c|c|}
\hline How do you sort or sift through waste & Frequency $(\mathrm{N}=60)$ & Percent (\%) \\
\hline Hooks & 4 & 7.00 \\
\hline Hooks and bare hands & 56 & 93.00 \\
\hline Total & 60 & 100 \\
\hline \multicolumn{3}{|c|}{ What materials do you often recover from the landfill } \\
\hline Plastics & 36 & 60.00 \\
\hline Metals & 24 & 40.00 \\
\hline Total & 60 & 100 \\
\hline \multicolumn{3}{|c|}{ Do you use personal protective equipment during scavenging } \\
\hline Yes & 23 & 38.30 \\
\hline No & 37 & 61.70 \\
\hline Total & 60 & 100 \\
\hline \multicolumn{3}{|l|}{ If yes how often } \\
\hline Always & 13 & 57.00 \\
\hline Sometimes & 10 & 43.00 \\
\hline Total & 23 & 100 \\
\hline \multicolumn{3}{|c|}{ Do you know the importance of personal protective equipment } \\
\hline Yes & 58 & 96.70 \\
\hline No & 2 & 3.30 \\
\hline Total & 60 & 100 \\
\hline \multicolumn{3}{|c|}{ Do you know that landfills are a source of pathogens and vectors } \\
\hline Yes & 58 & 96.70 \\
\hline No & 2 & 3.30 \\
\hline Total & 60 & 100 \\
\hline \multicolumn{3}{|c|}{ Do you know that hazardous waste is disposed at the landfill } \\
\hline Yes & 57 & 95.00 \\
\hline No & 3 & 5.00 \\
\hline \multicolumn{3}{|c|}{ Do you know that long term exposure to landfill gas is detrimental to your health } \\
\hline Yes & 48 & 80.00 \\
\hline No & 12 & 20.00 \\
\hline Total & 60 & 100 \\
\hline
\end{tabular}


Majority of the respondents mentioned income and employment as the importance of scavenging (Table 4). Only few of them said it helps reduce waste on the landfill site. The respondents suggested source of income to be their motivation for scavenging. Similar study by [10] observed $31.50 \%$ of the respondents in a Lagos dumpsite said their reason or motivation for scavenging was economic (based on the need to survive).

Most of the respondents said they were not happy working as scavengers. This was supported by the fact that almost all the respondents expressed interest in leaving the occupation when presented with an alternative (Table 4). Even though scavenging may be beneficial economically and environmentally, a significant number of scavengers are not happy with their current working conditions and find scavenging unpleasant. This finding contradicts that of [27] who reported that about $90 \%$ of the respondents said they found scavenging pleasant.

Table 4

Motivation for scavenging in the Gbalahi Landfill Site

\begin{tabular}{|lcc|}
\hline The importance of scavenging & Frequency $(\mathbf{N}=\mathbf{6 0})$ & Percent (\%) \\
\hline Source of income and employment & 58 & 98.00 \\
\hline Reduces waste on the landfill & 2 & 2.00 \\
\hline Total & 60 & 100 \\
\hline Are you happy with this work & & 28.30 \\
\hline Yes & 17 & 71.70 \\
\hline No & 43 & 100 \\
\hline Total & 60 & 95.00 \\
\hline Do you wish to leave this occupation when presented with an alternative \\
\hline Yes & 57 & 5.00 \\
\hline No & 3 & 100 \\
\hline Total & 60 & \\
\hline
\end{tabular}

\section{Health Risk, Protection Behaviour And Safety Practices}

All the respondents practice hand washing with soap (Table 5). This response does not reflect the reality on the ground owing to the unavailability of clean potable water around the landfill site. Almost all of the respondents always take their bath with few taking their bath sometimes (Table 5). Some respondents however alluded that other members of their households will not allow them to touch materials in the house till they washed their hands or took their baths. Majority of the respondents do not wash their clothes at all since those clothes are only wore to the landfill for scavenging. This practice can be a source of pathogens that cause skin diseases.

Most of the respondents eat or cook in the landfill site, this was mostly practice by nursing mothers and children. This practice poses a health threat since flies were mostly hovering around and could transmit other diseases. This is could be the reason why most of them complained of diarrhoea (Figure 2).

Most of the respondents have experienced physical abuse by other scavengers (Table 5). This sometimes results from misunderstandings about ownership of recovered waste materials and bullying. Almost half of the respondents have been discriminated against because of scavenging with a significant. The study showed a weak but significant negative 
correlation between age of respondents and psychological / emotional trauma $\left(r=-0.282^{\star}\right)$. Thus, the younger population are most likely to be emotionally or psychologically affected by scavenging. According to the [36], depression is one of the leading causes of illness and disability among adolescents, and suicide is the second leading cause of death in adolescents. Violence, poverty, humiliation and feeling devalued can increase the risk of developing mental health problems amongst children and adolescents [36]. This observed phenomenon may go a long way in negatively impacting their mental health and education. However, majority of the respondents do not seek counseling. This finding corroborates that of [37] who posit that children and adolescent mental health (CAMH) disorders are becoming prevalent globally. However, access to mental and psychological health care especially in developing countries like Ghana is generally limited and inadequate. The treatment gap for mental and psychiatry related disorders is at about $98 \%[38]$.

Majority of the respondents do not use drugs such as antidepressants, painkillers, alcohol, tobacco amongst others to help them in scavenging. However, few of them sometimes use painkillers which have not been prescribed by a professional physician. This was because of the tedious nature of scavenging and as a result they usually end up with general body pains. The observed practice presents a threat of misdiagnoses and drug abuse which might have adverse health impacts on their health in the long run. 
Table 5

Health risk, protection behaviour and safety practices in the Gbalahi Landfill Site

\begin{tabular}{|c|c|c|}
\hline Do you eat or cook on the landfill & Frequency $(\mathrm{N}=60)$ & Percent (\%) \\
\hline Yes & 53 & 88.30 \\
\hline No & 7 & 11.70 \\
\hline Total & 60 & 100 \\
\hline \multicolumn{3}{|l|}{ How often do you wash your clothes } \\
\hline Sometimes & 25 & 41.70 \\
\hline Not at all & 35 & 58.30 \\
\hline Total & 60 & 100 \\
\hline \multicolumn{3}{|l|}{ How often do you take your bath } \\
\hline Always & 57 & 95.00 \\
\hline Sometimes & 3 & 5.00 \\
\hline Total & 60 & 100 \\
\hline \multicolumn{3}{|c|}{ Have you been physically abused by others in your field } \\
\hline Yes & 37 & 61.70 \\
\hline No & 23 & 38.30 \\
\hline Total & 60 & 100 \\
\hline \multicolumn{3}{|c|}{ Are you discriminated against because of scavenging } \\
\hline Yes & 25 & 41.70 \\
\hline No & 35 & 58.30 \\
\hline Total & 60 & 100 \\
\hline \multicolumn{3}{|c|}{ Are you emotionally / psychologically affected by scavenging } \\
\hline Yes & 20 & 33.30 \\
\hline No & 40 & 66.70 \\
\hline Total & 60 & 100 \\
\hline \multicolumn{3}{|c|}{ Do you use drugs or medicines in order to help you work } \\
\hline Yes & 6 & 10.00 \\
\hline No & 54 & 90.00 \\
\hline Total & 60 & 100 \\
\hline \multicolumn{3}{|c|}{ Are you adversely affected by the weather } \\
\hline Yes & 58 & 96.70 \\
\hline No & 2 & 3.30 \\
\hline
\end{tabular}




\begin{tabular}{|c|c|c|}
\hline Do you eat or cook on the landfill & Frequency $(\mathrm{N}=60)$ & Percent (\%) \\
\hline Total & 60 & 100 \\
\hline \multicolumn{3}{|c|}{ Have you been pierced by a hypodermic object (syringe) or a sharp object } \\
\hline Yes & 48 & 80.00 \\
\hline No & 12 & 20.00 \\
\hline Total & 60 & 100 \\
\hline \multicolumn{3}{|c|}{ Have you been bitten by an animal or insect during scavenging } \\
\hline Yes & 49 & 81.70 \\
\hline No & 11 & 18.30 \\
\hline Total & 60 & 100 \\
\hline \multicolumn{3}{|c|}{ Have you accidentally fallen whilst scavenging on the landfill } \\
\hline Yes & 39 & 65.00 \\
\hline No & 21 & 35.00 \\
\hline Total & 60 & 100 \\
\hline \multicolumn{3}{|c|}{ Have you accidentally ingested any liquid or chemical whilst scavenging } \\
\hline Yes & 18 & 30.00 \\
\hline No & 42 & 70.00 \\
\hline Total & 60 & 100 \\
\hline \multicolumn{3}{|c|}{ Averagely how much do you spend on medication monthly (GHç) } \\
\hline $1-50$ & 56 & 93.30 \\
\hline $51-100$ & 4 & 6.70 \\
\hline Total & 60 & 100 \\
\hline \multicolumn{3}{|l|}{ Do you have health insurance } \\
\hline Yes & 36 & 60.00 \\
\hline No & 24 & 40.00 \\
\hline Total & 60 & 100 \\
\hline
\end{tabular}

Almost all the respondents complained about the weather which they said has dire impacts on their health (Table 5). Majority of the respondents alluded to the fact that they have been pierced by a hypodermic or sharp object during scavenging (Table 5). This poses a health threat since hospital waste are disposed of in the landfill. Scavengers can be exposed to hazardous waste materials in the landfill which may be a transmission point of diseases such as the dreaded acquired immunodeficiency syndrome (HIV/AIDS), tetanus, amongst others. Since, [39] reported that some health facilities do no properly segregate and / or incinerate waste before disposal in the landfill site. Scavengers are usually victims of bee stings and mosquito bites. This may be the reason why scavengers complained of malaria cases. There have been a few instances of snake and scorpion bites on the landfill and the absence of a first aid box makes these occurrences potentially fatal. 
Majority of the scavengers have fallen whilst scavenging (Table 5), as they tried to ascend and / or descend the heap of waste or trying to lift heavier objects than they can carry. Few of the respondents have accidentally ingested chemicals whilst scavenging that have accidentally splashing into their mouths. All the respondents alluded that they are irritated by the obnoxious odour from the landfill.

Majority of the respondents have health insurance and spend between $\mathrm{GH} \dot{c} 1.00$ to $\mathrm{GH} \not \mathbf{5 0 . 0 0}$ a month on health (Table 5). This is about half of their monthly income and expenditure on health could increase in the long run if safety and health precautions are not strictly adhered to. Some diseases or health conditions experienced by the respondents within the last 12 months (Figure 2).

\section{Covid-19 risk behaviour and waste generation}

The Covid-19 pandemic has disrupted and negatively affect a myriad of human livelihood including issues bothering on waste management. The increased production and use of PPEs as well as the changes in consumption patterns in major cities as a result of lockdown measures imposed by authorities has significantly impacted the rate and composition of waste generation globally. It is reported that, 129 billion face masks and 65 billion gloves are used every month worldwide [40]. The Asian Development Bank (ADB) reported that there has been a marked increase in waste and biomedical wastes in most Asian cities. In the Hubei province for instance infectious medical waste increased by about 6 folds as a result of Covid-19. This observed waste generation pattern has varied implications as far as sustainable waste management and waste scavenging is concerned [41, 42].

It was observed that in terms of Covid-19 risk behaviours, majority of the respondents risk being exposed to the virus and pathogens. As, the disposal of biomedical waste at the landfill has been reported [39]. Improper disposal of healthcare and biomedical wastes is strongly associated with public health outcomes [43, 44]. Similarly, disposable facemasks, face-shields, used tissues and reusable facemasks are becoming a major part of domestic household waste and may serve as contact sources or points of the covid-19 virus. The UNEP [41] reports that there is an increase in the amount of mixed waste (infectious wastes inclusive) owing to reduced waste segregation at source. The tendency to reuse scavenged or salvaged waste materials especially reusable facemasks and face shields as observed is a risk factor in terms of exposure of the waste scavengers to Covid-19. The rush to salvage waste whenever skip trucks freshly dispose of waste and the grouping of scavengers under trees and makeshift structures without recourse to social / physical distancing protocols is a major risk factor observed. The inadequate use of PPEs and poor handwashing practices owing to the absence of potable water and handwashing facilities on site pose risk for the scavengers. The length of time spent at the landfill is also a major risk factor. The perception that they have been fortified against "dirt" diseases through the use of herbs during childhood and the lack of awareness about the effects and risks of Covid-19 maybe reasons accounting for the observed indifference towards ensuring their own personal safety and protection. [45] posits that informal waste workers are at a high risk of been exposed to Covid-19 (SARS-CoV2) owing to the nature of their work and prevailing working conditions.

\section{Conclusion}

Scavengers in the landfill play a very significant and pivotal role in sustainable waste management and ensuring environmental health. Scavengers have fair knowledge about the health hazards associated with scavenging but believed it has an insignificant threat to their physical, social and mental well-being. Scavengers are motivated by the monetary or economic gains. A significant number of scavengers on the landfill do not use personal protective equipment. Safety and protection behaviour and practices are limited to the use of pieces of clothes to cover the nose, wearing of multiple clothes and worn-out boots recovered from the landfill. Hand washing culture is often practiced by 
scavengers off-site but sparingly not in the landfill site. Occupational health hazards associated with scavenging are biological, physical and psychological. Covid-19 health risks behaviours, majority of the respondents risk being exposed to the virus and pathogens. It is recommended that education and increased sensitisation should be encouraged and implemented by the EPA, Ghana Health Service and other allied institutions in order to regularise and ensure the health and safety of waste scavengers. Scavengers less than 15 years old should not be allowed to scavenge in accordance to Sections 58 to 61 of the labour Act.

\section{Declarations}

\section{Ethics approval and consent to participate}

Respondents consent was sorted and confidentiality was ensured prior to the interviews.

\section{Consent to publish}

All authors allow the publication of the paper.

\section{Availability of data and materials}

If requested, we are available to disseminate the data of the paper.

\section{Competing interests}

The authors of this research article have no conflict of interest.

\section{Funding}

The research was self-financed by the authors.

\section{Authors' contributions}

JGN, ABD and NB contributed equally in conceptualisation, writing and revising of the manuscript. All authors read and approved the final manuscript.

\section{Acknowledgements}

The authors are very grateful to the scavengers for responses and time, editors and anonymous reviewers for their suggestions and comments for improving the manuscript quality.

\section{References}

1. Samwine T, Wu P, Xu L, Shen Y, Appiah E, Yaoqi W. Challenges and prospects of solid waste management in Ghana. International Journal of Environmental Monitoring Analysis. 2017;5(4):96-102.

2. Kusi E, Nyarko AK, Boamah LA, Nyamekye C. Landfills. Investigating its operational practices in Ghana. International Journal of Energy Environmental Science. 2016;1:19-28.

3. Igwe PU, Anaje EC, Onyegbu CU, Ezechilue FB, Nwatu MT. A review of scavenging as a means of environmental management. International journal of Rural Development Environment Health Research. 2018;2:10-7.

10.22161/ijreh.2.1.2.

4. Aljaradin M, Persson KM, Sood M. The role of informal sector in waste management, a case study; Tafila-Jordan. Resources Environ. 2015;5(1):9-14. 
5. Medina M. Solid wastes, poverty and the environment in developing country cities: Challenges and opportunities (No. 2010, 23). Working paper//World Institute for Development Economics Research. 2010.

6. van Eerd M. The occupational health aspects of waste collection and recycling: an inventory study in India. 1997.

7. Ejares JA, Paler MKO, Aguilar MEL. Socio-demographic profile of scavenging households in Umapad dumpsite, Mandaue city Cebu, Philippines. Journal of Sustainable Development Studies, 2014;6(1).

8. Ezeah C, Roberts CL, Phillips PS, Mbeng LO, Nzeadibe TC. Evaluation of public health impacts of waste scavenging in Abuja Nigeria, using Q-methodology. In Proceedings of the ISWA/APESB World Congress, 12-15 October 2009, Lisbon, Spain. 2009.

9. United Nations Environment Programme. Health and safety guidelines for waste pickers in South Sudan. South Sudan: UNEP South Sudan. 2013. Available from:

http://wedocs.unep.org/bitstream/handle/20.500.11822/19536/health_safety_guidelines_waste_SouthSudan.pdf? sequence $=1$ \&isAllowed $=\mathrm{y}$.

10. Afon A. A survey of operational characteristics, socioeconomic and health effects of scavenging activity in Lagos, Nigeria. Waste Manage Res. 2012;30(7):664-71.

11. Medina M. Scavenging in America: back to the future? Resour Conserv Recycl. 2001;31(3):229-40.

12. Navarrete-Hernandez P. Scavenging revisited: supporting scavengers in Santiago de Chile. The ideal city: between myth and reality. representations, policies, contradictions and challenges for tomorrow's urban life. 2015.

13. Birkbeck C. Garbage, industry, and the 'vultures' of Cali, Colombia. Casual work and poverty in Third World cities, 1979;161-183.

14. Medina M. The world's scavengers: salvaging for sustainable consumption and production. Rowman Altamira. 2007.

15. Joshi A, Moore M. Institutionalised co-production: unorthodox public service delivery in challenging environments. Journal of Development Studies. 2004;40(4):31-49.

16. Allen A, Dávila JD, Hofmann P. The peri-urban water poor: citizens or consumers. Environment Urbanization. 2006;18(2):333-51.

17. Ostrom E. Crossing the great divide: coproduction, synergy, and development. World development. 1996;24(6):1073-87.

18. Pandey R. Sweepers and scavengers in third world cities: a study on occupational health problems of sweepers and scavengers of Kathmandu, Nepal (Master's thesis), 2004.

19. Medina M. Scavenger cooperatives in Asia and Latin America. Resources conservation recycling. 2000;31(1):5169.

20. Binion E, Gutberlet J. The effects of handling solid waste on the wellbeing of informal and organized recyclers: a review of the literature. Int J Occup Environ Health. 2012;18(1):43-52.

21. Ghana Statistical Service. 2010 population and housing census final results.

Availablehttp://statsghana.gov.gh/gsscommunity/adm_program/modules/downloads/get_file.php?file_id=27. 2012; Accessed July, 2021.

22. Padgett DK. Qualitative methods in social work research. Sage Publications. 2016;36.

23. Saunders B, Sim J, Kingstone T, Baker S, Waterfield J, Bartlam B, Jinks C. Saturation in qualitative research: exploring its conceptualization and operationalization. Quality quantity. 2018;52(4):1893-907.

24. Grady MP. Qualitative and action research: A practitioner handbook. Phi Delta Kappa International; 1998.

25. Asibor IG, Edjere O. Assessment of the activities of scavengers and their economic impacts in waste recovery in Warri metropolis, Delta State Nigeria. International Research Journal of Public Environmental Health. 2017;4(2):22- 
9.

26. Obadina A, Fisher J. Socio-economic demography of waste workers on Lagos dumpsites: analysis of gender differences, 2014.

27. Olufayo O, Omotosho BJ. Waste scavenging as a means of livelihood in south western Nigeria. Pakistan Journal of Social Sciences. 2007;4(1):141-6.

28. Salau O, Sen L, Osho S, Adejonwo-Osho O. Empirical investigation of formal and informal sectors in waste recycling of the municipal waste management system of developing countries: The case study of Lagos State. Journal of environment ecology. 2016;7:21-33.

29. Ikechukwu EE. Assessment of the activities of scavengers in Obio/Akpor local government, Rivers State, Nigeria. Journal of Environmental Protection. 2015;6(03):272.

30. Seidu AA, Ahinkorah BO, Darteh EKM, Dadzie LK, Dickson KS, Amu H. Prevalence and correlates of truancy among in-school adolescents in Ghana: evidence from the 2012 global school-based student health survey. Journal of Child Adolescent Mental Health. 2019;31(1):51-61.

31. Perry H, Gray J, Cole P, Abdulai A. Education sector analysis on cost and finance in Ghana. Final Thematic Report. 2018.

32. Ministry of Education. Education Sector Analysis 2018. Ministry of Education, 2018;1-87.

33. United Nations Environment Programme. Health and safety guidelines for waste pickers in South Sudan. South Sudan: UNEP South Sudan. 2013. Available from:

http://wedocs.unep.org/bitstream/handle/20.500.11822/19536/health_safety_guidelines_waste_SouthSudan.pdf? sequence=1\&isAllowed $=y$

34. Marello M, Helwege A. Solid waste management and social inclusion of waste pickers: opportunities and challenges. Latin American Perspectives. 2018;45(1):108-29.

35. Creel L. Children's environmental health: risks and remedies. 2002; Available from: https://www.prb.org/childrensenvironmentalhealthrisksandremedies/. [Accessed: 12th July 2021].

36. WHO. Adolescents: health risks and solutions.. 2018. Available from: https://www.who.int/news-room/factsheets/detail/adolescents-health-risks-and-solutions. [Accessed: 15th July 2021].

37. Kleintjes S, Lund C, Flisher AJ. A situational analysis of child and adolescent mental health services in Ghana, Uganda, South Africa and Zambia. African Journal of Psychiatry, 2010;13(2).

38. Eaton J, Ohene S. Providing sustainable mental health care in Ghana: A demonstration project. In: Providing Sustainable Mental and Neurological Health Care in Ghana and Kenya: Workshop Summary. National Academies Press (US); 2016.

39. Husein H, Musah BA, Guo E. Disposal of health facility waste in landfill sites and its effects on the people of Gbalahi community in the Tamale Metropolis. Int Res J Public Environ Health. 2014;1(1):1-9.

40. Prata JC, Patrício Silva AL, Walker TR, Duarte AC, Rocha Santos T. COVID-19 pandemic repercussions on the use and management of plastics. Environ Sci Technol. 2020;54(13):7760-5.

41. UNEP. Waste management during the COVID-19 Pandemic: From Resource to Recovery. United Nations Environment Programme. 2020. https://www.unenvironment.org/resources/report/waste-management-duringcovid-19-pandemic-response-recovery.

42. Asian Development Bank. Managing infectious medical waste during the COVID-19 pandemic. 2020;1-2.

43. Khobragade DS. Health care waste: avoiding hazards to living and non-living environment by efficient management. Fortune J Health Sci. 2019;2:014-29. 
44. Radin-Mohammed RMS, Al-Gheethi AA, Efaq AN, Abdullah AH, Kassim AHM. Health risk associated with management of municipal solid wastes in Malaysia, 2016.

45. Rahman MM, Bodrud-Doza M, Griffiths MD, Mamun MA. Biomedical waste amid COVID-19: perspectives from Bangladesh. The Lancet. Global Health, 2020.

\section{Figures}

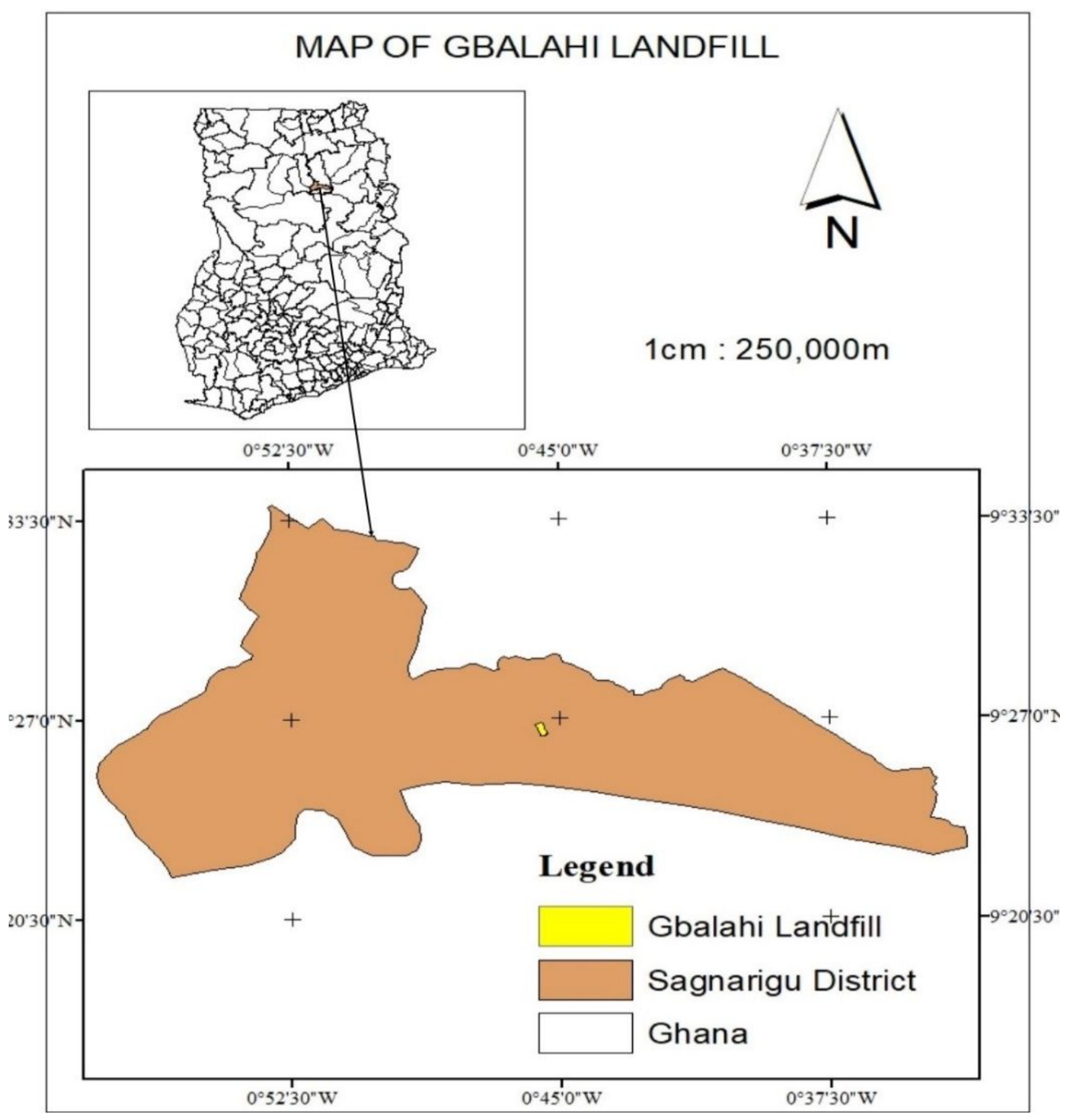

Figure 1

Map of the Gbalahi Landfill site 


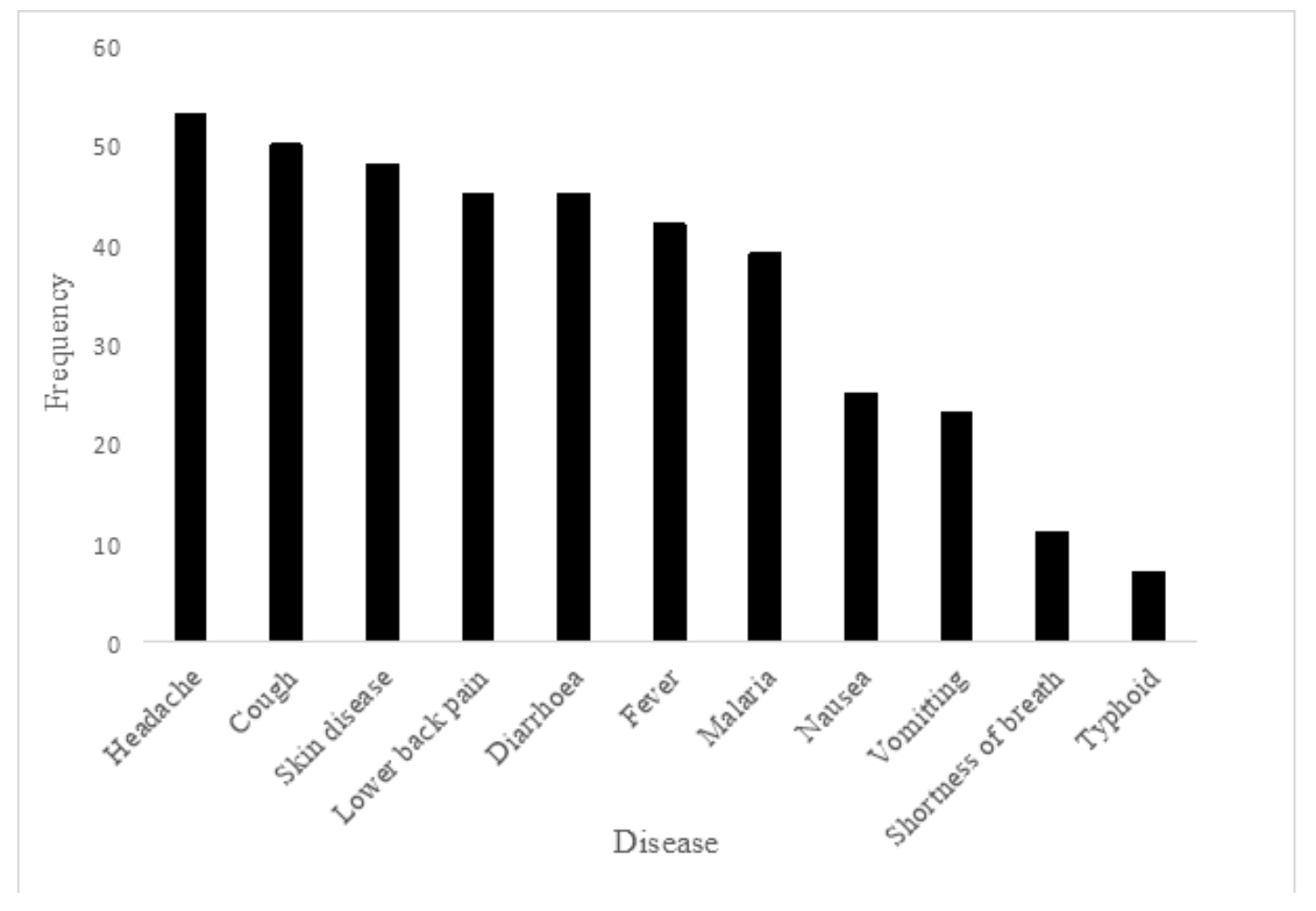

Figure 2

Diseases / health conditions recorded by the scavengers in the last 12 months in the Gbalahi Landfill Site 